\title{
Zinc Rich Paint のありかたについて
}

\section{長田蓼男}

Zinc Rich Paint とはその名称の示すよう にサビ止顔料として亜鉛末をきわめて豊富に 使用したサビ止塗料であって，一般のサビ止 塗料と異なり陰極防食能を具備することを特 徵としたサビ止塗料であります.そしてアメ リカではその生産量が急激に増加しつつあっ て，最近五力年間に数百\%の成長を示してい る現状であります.したがって近い将来にサ ビ止塗料中で王座を占めるのではないかとさ え期待されているサビ止塗料の一つでありま 于.

亜鉛末をサビ止塗料に使用することはわが 国でもすでに40年以上も以前から行われてき たもので，東覀ペイント株式会社が“ガルバ 一”といら商品名で市場に発売し関東震災後 の帝都復興に一役買って出たことはわが塗料 界でもよく知られているところであります.

しかしこの種の塗料は単なる亜鉛末サビ止塗 料であって従来のサビ止塗料と軌を同じくす るもので近時提唱されているところの陰極防 食能を具備していなかったのであります.

ところが最近十余年以前より, 亜鉛末の微 細化技術の進歩とこれに適する展色剂の開発 により，かつまた Pass, Blowes ならびに Meason 氏等の諸氏による亜鉛末を使用した 塗料の基礎的研究が発表されるに及んで，陰 極防食能を具備する亜鉛末塗料，すなわち Cold Galvanizable Paint として Zinc Rich Painた の開発を見るに至ったのであります.

すなわち Pass 氏は1952年の論文で次のよ うなことを指摘したのであります氏氏は形成
塗膜中の亜鉛末量を65～95重量\%になるよう に調製した一連の塗料をそれぞれ約 $5 \mu$ の厚 みに鉄面に塗布しその塗膜の電気伝導性を測 定した結果, 亜鉛末をきわめて豊富に使用し た場合塗膜中の金属亜鉛粒子が相互間ならび に被塗鉄面との間に電気的接触を保ち得るこ とを証明し，塗料による鉄鋼の陰極防食が可 能であることを確認したのであります．そし てこのような性能を発揮するには金属亜鉛量 を塗膜中に 90～95重量\%にすればよいと提唱 したのであります. したがって Zinc Rich Paint とはその形成塗膜中金属亜鉛分を90〜 95重量\%含有し陰極防食能を具備することを 特徵とする亜鉛末塗料と定義することが一般 通念とされるようになったのであります。

その後の Zinc Rich Paint の 発展過程を 展望しまするに，塗膜中の金属亜鉛量を90 95重量\%とする通念に促われすぎる感があっ て,この種塗料の改良は専ら亜鉛末を十分に 結合し被塗鉄面によく密着せしめ，かつ塗膜 に機械的に優れた性質を付与するところの展 色剂の選択に重点を置いて行われていたよう であります。そして現在ではェポキシ系の展 色剤が最も優れたものの一つであるようにい われエポキシ系 Zinc Rich Paint が市場を 賑わしている現状であります。

しかし私達はいま一度 Zinc Rich Paint のありかたについて検討を加える必要がある のではないかと思います.すなわち Zinc Rich Paint はその形成する塗膜中に 分散し て配列される金属亜鉛粒子が相互間ならびに 
被塗鉄面との間に電気的接触を保持するよう に調製されなければなりません。だから従来 の通念とする塗膜中の金属亜鉛の重量\%の規 制よりるむしろその容量\%の規制について論 じなければならないのであります，幸いなこ とには私達が現在入手できる亜鉛末はそのほ とんどすべてが蒸留法で製造されていて大部 分が球状を保っています。したがって上記の 条件をみたすためには，塗膜中に亜鉛粒子の 占める容量\%は次式で示す值の範囲内である ことを要します。

$$
\begin{aligned}
\text { P.V.C }= & \left(\frac{1}{\sqrt{3} r}-\frac{2 \sqrt{3}-3}{3}\right)^{3} \times \\
& \frac{4}{3} \pi r^{3} \sim\left(\frac{1}{2 r}\right)^{3} \times \frac{4}{3} \pi r^{3} \\
= & 80.5 \sim 52.4 \%
\end{aligned}
$$

$r:$ 亜鉛粒子の半径

今亜鉛の比重を 7.0 , 展色剂の比重を 1.0 1.4としますと, P.W.C $\fallingdotseq 84.5 ９ 6.7 \%$ とな ります.この結果は Pass 氏の論文の結論を よりよく説明することになります。

また私が平均粒度径 $1 \mu$ ，金属亜鉛分 96.5 重量\%の亜鉛末とエポキシ系展色剂で調製し た Zinc Rich Paint そついて実験した結果 P.V.C 55容量\%(金属分のみのP.V.C 約53\%) で初めて陰極防食性を示すことを確認するこ とができました。一方 P.V.C がこのように 大きくなった場合, 実際に形成する塗膜の厚 みが亜鉛と展色剈との真比重より算出した計 算値より大きくなることがしばしばあります すなわち， $D$ (実測值) $\geqq D$ (計算値)

このような結果は乾燥過程中に行われる覀 鉛粒子と展色剂間に起る物理的相互作用に起 因するものでありまして P.V.C の上限であ る $80 \%$ 亿近づけば近づくほぞ，時には亜鉛粒 子の相互接触さえ阻害されることも当然推測 されるのであります。すなわお

$[D$ (実測値 $)-D$ (計算値) $] / D$ (実測值) 一応 Zinc Rich Paint 塗膜の 気孔率と考
えることができます。この值は同一の亜鉛末 および展色剤基質を使用した等しい P.V.Cの 塗料について溶㓮を变化しただけで区々の值 を示するのであります。この值が 0 亿近いほ どその塗膜の機械的強度が優れていることは 容易淮測されるのであります，今平均粒度 径 $1 \mu$, 金属亜鉛分 96.5 重量\%の亜鉛末と展 色剂基質を使用し P. V.C $60 \%$ の塗料につい て， A, B, C と組成の異なる溶剂を使用した 場合の気孔率を測定し次のよ5な結果を得て 特ります。

$\begin{array}{lr} & \text { 気孔率 } \\ \text { A } & 0.30 \\ \text { B } & 0.15 \\ \text { C } & 0.05\end{array}$

したがって Zinc Rich Paint の調製にあ たっては亜鉛粒子，展色剂基質特よび溶剤の 三成分についてのそれぞれの物理的性質なら びに相互関係に留意し適切な配慮を必要とす るのであります。いか展色剤が優秀とされ ていてもその溶剤の選定を誤るときにはその 展色珮の効果を十分に発揮することができな いのであります。 上記しましたように Zinc Rich Paint の改良関しましては展色剤の 選定もさることながら，塗膜形成時に和ける 亜鉛粒子の配列の追求汇関する数多くの基礎 的研究が今後に残された重要研究問題である といらことができるのであります。したがっ て数多くの研究者がこの研究課題ととり組ん でいただきたいと念願する次第であります。

な特季た Zinc Rich Paint の本質からこ れを今少し広義保解釉して Zinc Rich Paint とはサビ止顔料として亜鉛末を豊富に使用し てかつ陰極防食能を具備する塗料であると定 義されるべきと考光るのであります。そらす れば Zinc Rich Paint の新たな進展も期待 でき新規研究分野も拡大するのではないかと 考觉られます。

次に亜鉛末をサビ止塗料に利用した塗料の 
規格について調べてみますと,アメリカ連邦 規格 T.T.P. 641，日本工業規格执よび日本 国有鉄道規格 J.R.S. 13052等があります. そ してこれらの規格中 J.R.S. 規格だけは一応 Zinc Rich Paint と揭題されています. しか しいずれる Zinc Rich Paint の本質を規制 しておりません，けれども共通して規制され ている点は, これらの塗料の比重が 2 以上で あるということができます。

一般に Zinc Rich Paint は亜鉛末塗料よ りさらに多量の亜鉛を使用するすのであって その比重がより大きくなるとの通念にとらわ れるものであります. そのため Zinc Rich Paint は当然実用塗布面積 (俗にいう伸び) がきわめて小さくその効果がいかに優秀であ ろらと経済的に劣位にたたされるように考え られるのであります. したがってこの業界の 大メ一カーと目せられている 1，2の会社に 括いてさえZinc Rich Paint の将来性に疑 問をもっているように聞き及んでいます。し かしこうしたことは Zinc Rich Paint の本 質を正しく理解しないこと，执よび規格制定 にあたってこのような危惧を起さすことのな いような規格を定めることによって拉のずか ら解消されることと思うのであります。いず れ近い将来に招いて正しいZinc Rich Paint の規格も制定することになると思いますがそ の節には関係技術者の十分な検討を切望する 次第であります.

さて Zinc Rich Paint のサビ止能力, と りわけ水中括よび湿気の多い個所では他の-・ 般サビ止塗料に比して優秀であることはすで に多くの人々から認められていますが，その 実用面での問題について検討しますと次のよ ラであります。

第 1 の点は上記しましたように Zinc Rich Paint の比重が大きくなるということであり ます。しかし超微粒子の亜鉛末使用，亜鉛 末より比重が小さくて鉄より電気化学的に陽
性の他種活性金属の微粉を適量添加すること または亜鉛粒子の形状の選択などの手段によ って一般のサビ止塗料にほぼ近い比重のZinc Rich Paint を調製することも可能となりま す.す寸でに比重1.6である Zinc Rich Paint る開発されているようであります.

第 2 の点は Zinc Rich Paint の塗膜が水 中でフクレ現象（ブリスタリング）を起し易 いことであります．この点も前記同様の手段 でも一応補正することができるようでありま 于.

第 3 の点は Zinc Rich Paint 塗膜への上 塗々料の選択であります．この点は適当な中 塗々料の使用で容易に解決ができをす。一般 に適性なサビ止塗装は, サビ止塗料の塗装, 中塗々料の塗装, 上塗々料の塗装の 3 回塗装 が常識的に施行されている現状でありますか ら，実際問題としてのサビ止雓装に扣いては あまり問題にならないのであります.

第 4 の点は Zinc Rich Paint の 有効塗膜 厚みの問題であります.Zinc Rich Paint が 開発されてからまだ日が浅いため今日いかな る厚みに塗布されたら幾年間防食に有効であ るかといら点に関しては今後の径過を待つよ り外はないのであります. しかし無機質系の Zinc Rich Paint (亜鉛末 70 重量\%，ケイ酸 化合物 6.5 7 重量\%, 溶剤残重量\%) はか なり古くから使用されてきているものであっ て，鉄道技術研究所での実験結果によればそ の長期有效塗膜厚みは $40 \sim 60 \mu$ とされてい ます.しかしこれらの塗料に使用されていた 亜鉛末の平均粒度は約 $6 \mu$ であり，またその P.V.C は执よそ $80 \%$ でありますから, 次の 式より亜鉛粒子の配列層数は $4 \sim 7$ となるこ とが推測されます。

$$
\begin{aligned}
& 32 \mu<\frac{1}{2}\{2+(n-1) \sqrt{3}\} A<48 \mu \\
& \text { ただし } n: \text { 亜鉛粒子の配列層数 } \\
& A: \text { 平均粒度径 } \mu
\end{aligned}
$$


すなわち長期効力を期待するためには塗膜 中に亜鉛粒子が $4 \sim 7$ 層に配列される必要が あるということになります。一方無機質の Zinc Rich Paint に持ける平方メートル当り 覀鉛の消耗量は 15２0 gr/year とされて招 ります.したがって適当な有機質展色剂と超 微粒子の亜鉛末の使用によって有効塗膜の軽 減を計ることが容易に推測されるのでありま す.

第 5 の点はショッピングプライマーとして の使用に対する Zinc Rich Paint のありか たであります・ショットブラスト施工後の鋼 板に対するショッピングプライマーとして従 来は全般的にウォッシュプライマーの施工が 行われていたのでありますが， ウォッシュプ ライマーの有効期間は $2 \sim 3$ 力月位でありま す. 従ってな和气の有效期間を倍加する研究 もさることながら，これに替るべきプライマ 一として，Zinc Rich Paint が検討され実施 の段階に入っております。この場合問題とな るのが熔接作業後の熔接部の熔着金属に拉よ
ぼす影響等の問題であります，亜鉛害の問題 は作業環境の改善とその予防処置によって解 決できるでしょうが，上記しました点はZinc Rich Paint の調製上大いに考虑しなければ ならない問題であります．熔接作業上注意す べき点は展色剂基質の燃焼による水蒸気の発 生にあります。したがってこの問題はその基 質に水素成分のできるだけ少なく，かつN， $\mathrm{P}, \mathrm{S}, \mathrm{Cl}$ 等を含有することのない成分組成よ りなる粘結剤基質を使用することにより改善 することができることが期待し得られるので あります.

以上述べましたように，わが国ではZ Zinc Rich Paint が広く一般に寒用されるように なってからまだ数年しかたって拀りませんが 結論として上記の諸点を重点とし 軽比重の Zinc Rich Paint を開発することが Zinc Rich Paint に課せられた 最も重要研究課題 ということができるのであります.

(賀藤株式会社:千住工場)

\section{ゴムとプラスチック・ライニング

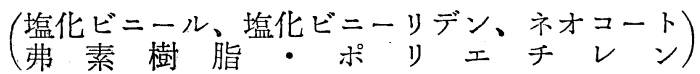 光沢メッキには是非！}

各種メッキ槽・酸洗槽・電解槽・濾過槽・ポンプ排風機 ライニング３0年の歴史と技術を誇る 大機ゴム工業 K K 代理店

坂 本 ゴム株 式 会 社 本

社 横浜市神奈川区二ッ谷町 32 T E L横浜(48)3204(代)

東京営業所 東京都港区芝田村町 4-5 